\title{
The Impact of Macroeconomic Variables on Stock Prices in Kuwait
}

\author{
Ahmad M. Al-Kandari ${ }^{1} \&$ Sadeq J. Abul ${ }^{2}$ \\ ${ }^{1}$ Associate Professor, Department of Insurance and Banking, College of Business Studies, State of Kuwait, \\ Kuwait \\ ${ }^{2}$ General Manager, Sray for Economic Consultancy, Daeyah, Kuwait \\ Correspondence: Sadeq J. Abul, General Manager, Sray for Economic Consultancy, P.O. Box 15103, Daeyah, \\ Kuwait, 35452, State of Kuwait, Kuwait. E-mail: sadeqabul@gmail.com
}

Received: April 72019

doi:10.5539/ijbm.v14n6p99
Accepted: May 5, 2019

Online Published: May 16, 2019

URL: https://doi.org/10.5539/ijbm.v14n6p99

\begin{abstract}
The Kuwaiti Stock Exchange was established in April 1977 and is among the oldest stock exchanges in the GCC countries. This study aims to add new evidence about the impact of macroeconomic factors on the Kuwaiti Stock Exchange. It examines empirically the dynamic relationship between the Kuwaiti Stock Exchange Index and the main macroeconomic variables. These variables included M2, the three-month deposit interest rate, oil prices, the US Dollar vs Kuwaiti Dinar exchange rate and the inflation rate. By applying the Johansen cointegration test, together with the Var Error Correction Model (VECM), the study found that there a long-run unidirectional relationship exists between the Kuwaiti Stock Exchange Index and the aforementioned macroeconomic variables. This study also confirmed the existence of a short-run relationship between oil prices and stock prices in Kuwait.
\end{abstract}

Keywords: Kuwait Stock Exchange, cointegration, vector error correction model (VECM), oil prices, macroeconomic variables

\section{Introduction}

Kuwait is an oil exporting country, situated at the northwestern corner of the Arabian Gulf, covering a land area of 18,000 square kilometres. The emergence of the modern Kuwaiti economy can be traced to 1946, when the first exports of oil were recorded. The estimated crude oil reserves of Kuwait are about 104 billion barrels, which amounts to $8 \%$ of the world's proven reserves. The Kuwaiti Stock Exchange (KSE) emerged after the country experienced excess liquidity from the oil revenues. The Kuwaiti Stock Exchange was established in April 1977. In fact, stock markets do not develop in a vacuum, but reflect the prevailing economic conditions. Stock markets play an important role in the modern economy. They mobilise and channel funds from surplus units to deficit units, which can use them more profitably. The oil prices play a crucial role in the Kuwaiti economy as, if the oil revenues rise, then the savings and government expenditure, which dominate the Kuwaiti economy, will rise also. It may be argued that an increase in oil prices may introduce the problem of absorptive capacity in Kuwait; oil revenues can simply cause inflated prices for land and stock assets. The examination of the effects of macro-economic factors on the stock market started with Ross's (1976) Arbitrage pricing theory (APT), who stated that stock returns are affected by certain macro-economic factors, which he explained as risk variables. After the publication of Ross's paper, the financial economics literature grew rapidly, and numerous studies appeared in the literature examining the relationship between the stock market and macro-economic variables. Some of these studies focused on the GCC countries, including Kuwait. However, the literature regarding the GCC countries focused mainly on the relationship between oil prices and the stock exchange, with few authors tackling the impact of macroeconomic variables on the stock exchange. The relationship between oil prices and the stock market in the GCC has received more attention from researchers than that between macroeconomic variables and the stock exchanges in the GCC countries; for example, Maghyereh and Al-Kandari (2007); Ravichandran and Alkhathlan (2010); Mohanty, Nandhs, Turkistani and Alaitani (2011); Alqattan and Alhayky (2016); Kisswani and Elian (2017); and Chiekh, Naceur, Kanaan and Rault (2018).

However, a small number of studies has examined the impact of macroeconomic variables on the Kuwaiti Stock Exchange (KSE, henceforth); for example, Al-Mutairi and Al-Omar (2007); Al-Shami and Ibrahim, (2013); Hayky and Naim (2016); and Merza and Almusawi (2016). This study aims to add new evidence regarding the impact of macroeconomic factors on the Kuwaiti Stock Exchange. The remainder of this paper will review the 
related literature, the Kuwaiti Exchange, and the empirical work, then discuss the results and conclusion.

\section{Related Literature Review}

There is a vast number of studies in the financial economics literature regarding the relationship between macroeconomic variables and stock prices. As mentioned earlier, part of this literature focused on the relationship between stock prices and oil prices in the GCC countries, while another part examined the relationship between macroeconomic variables (including oil prices) and stock prices. For the purpose of this study, the most relevant of these studies will be reviewed in this section. As mentioned earlier, the oil prices/stock market relationship has been documented by numerous researchers. For example, Maghyereh and Al-Kandari (2007) revealed a non-linear relationship between oil prices and stock markets in the GCC. Ravichandran and Alkhathlan (2010) argue that oil prices affect stock prices and transmit through major macroeconomic variables in the long-term equilibrium. By using daily stock price indices and oil prices for the period from March 2008 to April 2010, they investigated the impact of oil prices on the GCC stock markets. Their empirical results show that oil prices have a major effect on the liquidity of the GCC stock markets. Alqattan and Alhayky (2016) reveal an interesting result regarding the relationship between the GCC stock markets and oil prices. By using ARDL analysis, they find no long-run relationship between oil price and stock market prices for all GCC countries except for the stock market of Oman. In contrast, they confirm a positive short-run relationship between oil and stock prices in all GCC markets. Another study, by Mohanty, Nandhs, Turkistani and Alaitani (2011), concluded that oil price changes impact on the stock returns of all GCC countries except Kuwait. In a similar study, Kisswani and Elian (2017) examine the long-run oil price effects on the Kuwait stock exchange sector throughout 3 January 2000 to 9 December 2015 for some sectors, and 14 May 2012 to 9 December 2015 for others, using daily data. They argue that using a linear model to examine such a relationship might be an inappropriate method. Therefore, they applied non-linear ARDL tests and found a negative cointegration coefficient between stock prices and certain sectors, such as banks, industry, real estate and consumer services, while for other sectors of the KSE they did not find a significant relationship. Moreover, an insignificant relationship was found for the short-run dynamics. A recent study by Chiekh, Naceur, Kanaan and Rault (2018) examines the impact of oil price changes on GCC stock markets using monthly data from January 2004 to December 2015. They applied different econometric models (nonlinear regime-switching models) to capture the irregular effects of oil price differences and check for large shock effects. They concluded that, by using nonlinear STR and LSTR models, they could capture the two possible sources of asymmetry in stock price reactions. They found significant asymmetries in the relationship between oil prices and the stock markets in Oman, Qatar and Kuwait, and not in the case of Bahrain, Saudi, Arabia and UAE. However, besides the oil prices, which have been confirmed by most of the previous studies to be the main factor affecting the stock prices in the GCC markets, there are also traces of evidence of the impact of other macroeconomic variables which have identical effects on the GCC stock markets. These variables are: inflation, the money supply, GDP, the exchange rate, the unemployment rate, the industrial production index and the interest rate. Relevant studies regarding the relationship between macroeconomic variables and stock prices in other countries are also reviewed, for example: Karagoz, Ergun and Karagoz (2009) for Istanbul; Olugbenga (2011) for Nigeria; Kuwornu (2011) for Ghana; Momani and Alsharari (2012) for Jordan; Patel (2012) for India; Kalyanaraman and Al-Tuwajri (2014) for Saudi Arabia; Nijam, Ismail and Musthafa (2015) for Sri Lanka; Ndunda, Kingori and Ariemba (2016) for Nairobi; Badullahewage (2018) for Sri Lanka; and Ahmed, Aslam and Hakeem (2018) for Pakistan.

Karagoz, Ergun and Karagoz (2009) conducted a study on the Istanbul Stock Market for the period 1998-2008. Using a co-integration analysis, they find evidence of a long-run relationship between the Istanbul stock market index and the following variables: the interest rate, inflation, the industrial production index, the money supply (M1) and the real effective exchange rate. They reveal a positive relationship between the stock index and two macroeconomic factors, consumer price and the real exchange rate, while both the money supply and interest rate have negative effects. Moreover, no significant relationship between the stock market and real economic activity was found in this study. They argue that the positive effects of the exchange rate on stock lead to higher returns on the stock market as a result of the Turkish lira's depreciation. Olugbenga (2011) aims to examine how macroeconomic factors affect stock prices at the micro level on the Nigerian Stock Market during the period January 1985 to December 2009. The findings of this study reveal that GDP and oil have positive effects on stock prices, while interest rate and exchange rate have negative impacts, and no significant relationship was found for M2 and inflation rate. This study argues that some macroeconomic variables have a varying effect on stock returns. Therefore, it recommends that Nigerian investors should follow a diversifying strategy. Kuwornu (2011) examines the relationship between the inflation rate, oil prices, exchange rate, three months treasury bill 
rate and stock returns in the Ghana Stock Markets for the period January 1992 to December 2008. The study results show a significant negative relationship between stock returns and exchange rate and treasury, while a significant positive relationship between stock returns and the following variables: the consumer price index, exchange rate and Treasury bill rate. These results are not in line with Olugbenga's (2011) study which found a negative relationship between stock prices and interest rate. Momani and Alsharari (2012) investigate the effect of macroeconomic variables, such as interest rate, money supply, industrial product index and GNP, on stock prices in the Amman Stock Market in Jordan for the period 1992-2010. This study uses a stepwise multiple regression analysis and investigates the effects of those variables on the general price index and on the four main sectors of the stock market: industry, insurance, services and banks. The findings from this study show that these variables have an impact on both the general index and the sub-indexes. Patel (2012) found a long-run equilibrium relationship between macroeconomic variables such as: the interest rate, inflation, the exchange rate, industrial production, gold prices, silver prices, oil prices, and the money supply with the two main indices of the Indian stock market for the period January 1991 to December 2011. Another study was conducted by Masuduzzaman (2012) of developed countries: the UK and Germany. The study analyses the long- and short-run dynamics between the macroeconomic variables and stock returns for the Frankfurt and London stock markets for the period February 1999 to January 2011. The study finds mixed results for Frankfurt, for example, short-run causality runs from the stock price index to the consumer price index, from money supply to stock index and from industrial production to the stock price index, but long-run causality runs from the consumer price index to the stock price index and from the exchange rate to the stock price index. However, for the London stock market, the long-run causality runs from the consumer price index to the FTSE100, while short-run causality runs from the FTSE100 to the consumer price index, from the money supply to the FTSE100 and from industrial production to the FTSE100.

For a similar economy to Kuwait, a study was conducted by Kalyanaraman and Al-Tuwajri (2014) of the Saudi Arabia stock market. This study aimed to determine the long-run relationship between five macroeconomic factors and the Saudi all share index using monthly data from January 1994 to June 2013. The findings of the study reveal that factors apart from the S\&P500 Index have a significant relationship with the Saudi all share index. These relationships are as follows: the consumer price index has an inverse relationship with the Saudi share index while the money supply, exchange rate and industrial production have a positive relationship. In the case of the Indian stock market, Venkatraja (2014) explored the relationship between the industrial production index, wholesale, the gold price, foreign institutional investment, the real effective exchange rate and stock prices on the Indian Stock Exchange for monthly data for April 2010 to June 2014. The results reveal a strong influence of these variables on the stock prices on the Indian Stock Exchange. Samontarary, Nugali and Sasidhar (2014) examined three variables' (oil prices, exports and the PE Ratio) relationship with the stock market index of Saudi Arabia (TASI) and found a significant positive relationship between them. Nijam, Ismail and Musthafa (2015) identified the effect of macroeconomic factors, namely, GDP, interest rate, exchange rate, inflation and the balance of payment, on the stock price index of the Colombian Stock Exchange for the period 1980-2012, and found in strong causality between these factors and the stock market index of the Colombian Stock Exchange. Ndunda, Kingori and Ariemba (2016) examined the relationship between four macroeconomic factors (GDP, money supply (M3), inflation, and exchange rate) and the Nairobi Stock Market, and found a positive relationship between these factors and the average stock market capitalization. By using correlation analysis, they revealed a high correlation between these factors and market capitalization. However, their regression model showed insignificant coefficients for exchange and GDP. Badullahewage (2018) investigates the impacts of macroeconomic variables on stock prices in the Sri Lankan stock market (Colombo) throughout the period 1990-2012. The study finds a strong relationship between the all share price index of the Colombian Stock Exchange and macroeconomic variables. He finds a significant positive coefficient for interest rate, exchange rate and GDP but a negative significant coefficient for money supply. Ahmed, Aslam and Hakeem (2018) examined the effect of macroeconomic factors on Pakistani stock prices for the period 1993-2017. They concluded that there were no long- or short-run effects of interest rate, exchange rate and inflation on the stock market prices on the Pakistani Stock Exchange. Few researchers have studied the relationship between macroeconomic variables and Kuwaiti stock prices, but some of them have focused on a single variable, such as oil prices. Few of them investigate the effect of other macroeconomic variables, such as the money supply, interest rate, consumer price index, exchange rate and GDP. To our knowledge, the first study to examine the relationship between macroeconomic factors and Kuwaiti stock prices was conducted by Al-Mutairi and Al-Omar (2007). They investigated the impact of the following macroeconomic factors: the interest rate, money supply, inflation and government expenditure, on Kuwaiti Stock Exchange behaviour using monthly data for the period 1995 to 2005. Their findings reveal that macroeconomic variables have a limited long-run effect on all 
sectors of the KSE. The results obtained from the variance decomposition and impulse response show that $11 \%$ of the variation in the value of traded shares can be explained by macroeconomic factors. According to Al-Shami and Ibrahim (2013), there exists a positive relationship between inflation, money supply and oil prices and stock returns on the Kuwaiti Stock Exchange. Their research investigated the impact of five macroeconomic variables, including the inflation rate, interest rate, money supply, oil prices and unemployment rate. The Granger causality results indicate that bi-directional causality exists between the inflation rate, money supply (M2), and oil prices and stock returns. Their data cover the period from January 2001 to December 2010. Al-Hayky and Naim's (2016) findings reveal that the Kuwait Stock Exchange index has a positive relationship with oil prices during high volatility periods but no relationship during low volatility periods. Merza and Almusawi (2016) find that each sector of the Kuwaiti Stock Exchange is affected by different macroeconomic factors; for example, the banking sector has a relationship with a consumer price index, interest rate, oil price and gold price, while the real estate sector is influenced by the exchange rate, oil price and gold price. The insurance sector is affected by the money supply, houses prices and oil prices. For the whole market, they find that the gold price and deposit rate interest affect the Kuwaiti Stock Exchange. They used quarterly data from 2005-2015 and applied the OLS method. They argue that the official indices of the Kuwaiti Stock Exchange are not accurate indicators that reflect the behaviour of the market. Therefore, they used a simple average of the total value of traded shares divided by the volume of traded shares. Using an average value without weights and a base date will not necessarily reflect the market activity. There are three official indices for the Kuwaiti Stock exchange, which we think they reflect the stock market activity accurately.

\subsection{Review of the Kuwaiti Stock Exchange}

The Kuwaiti Stock Exchange (KSE, henceforth) originated after the country experienced excess liquidity from oil revenues. Three main factors determine the liquidity position in Kuwait: the oil revenues, government expenditure and credit of the banks and financial institutions. From the date of the first shareholdings company (the National Bank of Kuwait), established in 1952, until April 2 1977, the date of the Kuwaiti Stock Exchange's establishment in the Kuwait commercial centre, shares were traded between investors without any financial regulatory system. Moreover, since the KSE has been established, it has faced four crises. The first crisis occurred in 1977, the main reason being a lack of appropriate regulations. The second crisis arose in August 1982, when certain stocks were traded on the Al-Manakh market (as a parallel market). This market was completely free from any government control. The third crisis was due to the repercussions of the Iraqi invasion of Kuwait in August 1990 and the subsequent Gulf War. The fourth crisis was the World financial crisis in 2008. Since 2008, the Kuwaiti Stock Exchange (KSE) has witnessed positive regulatory changes that lead the Stock Market to be upgraded to the level of the other emerging stock markets across the world. In contrast, the KSE was promoted by the FTSE in 2018, while the S\&P Dow Jones promise to upgrade the KSE to an emerging market on 23 September 2019 (Abul, 2019). It may be argued that other factors that have been documented in the stock market literature during the last few decades may have an impact on the Kuwaiti Stock Exchange.

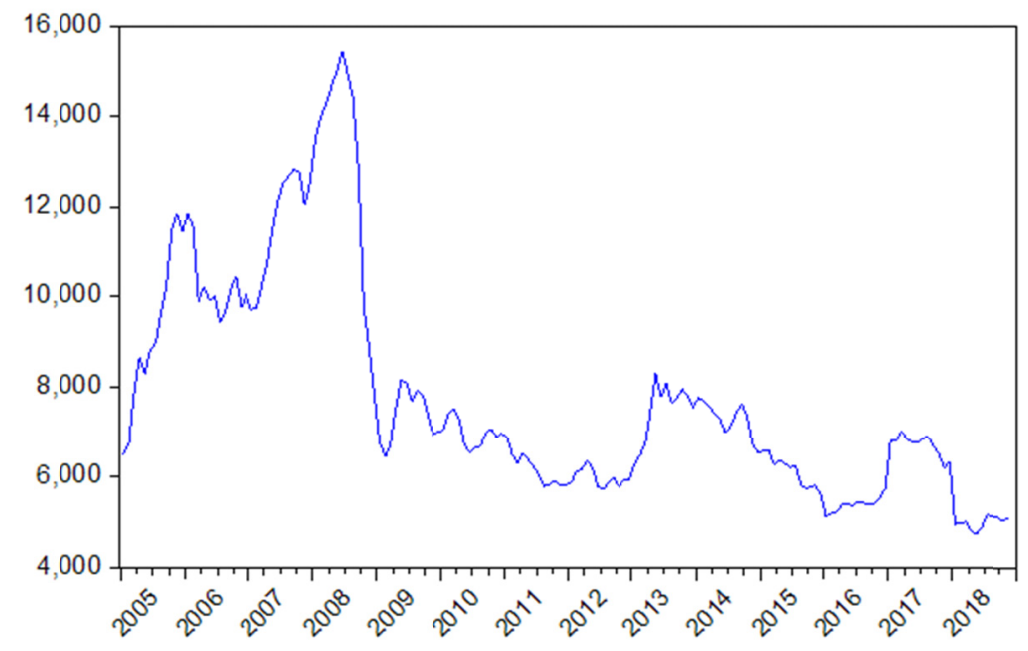

Figure 1. Kuwait stock market index

Figure 1 shows the development of the general Kuwait stock index during the investigated period. The effects of 
the world financial crisis in 2008 are shown clearly in this index, which fell sharply during this period.

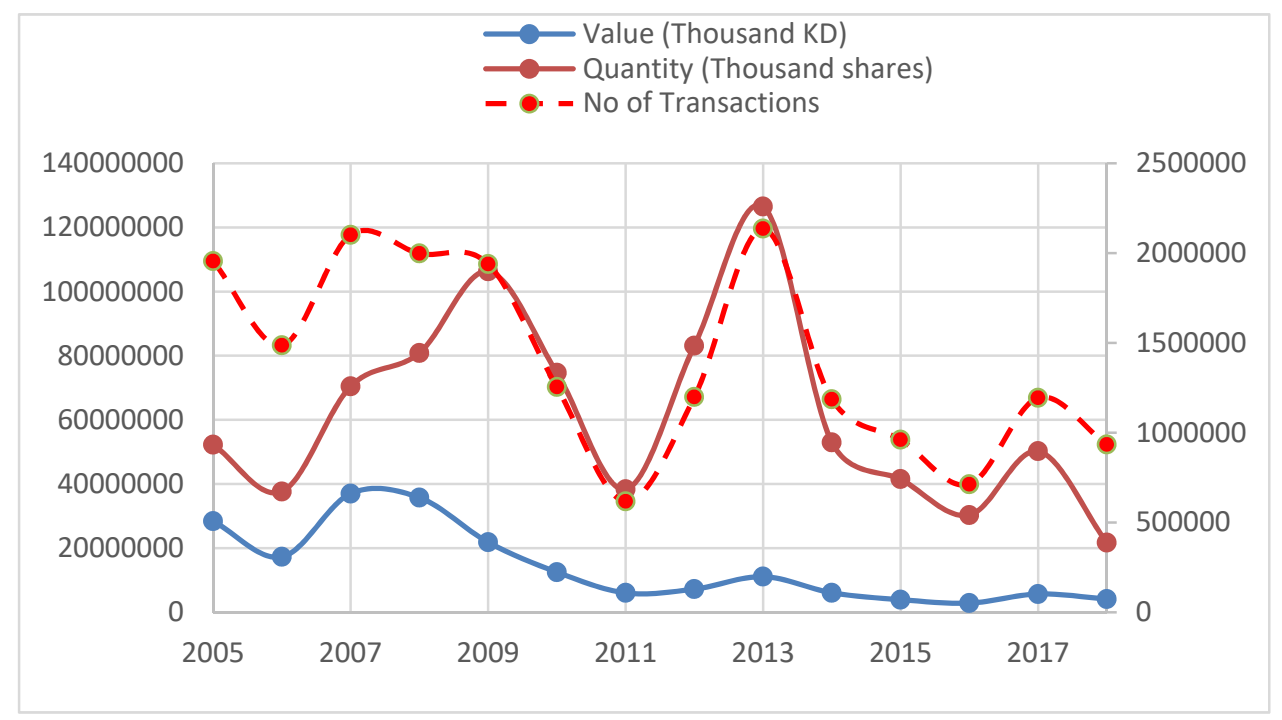

Figure 2. Kuwait Stock Exchange Traded Shares

Figure 2 shows the value and traded number of shares on the Kuwaiti Stock Exchange during the period 2005-2018, when the financial world crisis in 2008 profoundly affected the KSE in 2009. The value of traded shares reached its highest level in 2007 and started dropping sharply from 2008 to reach its lowest level in 2011. As mentioned earlier, the Kuwaiti economy has experienced an unprecedented rate of growth over a considerably long period and the sources of growth have been dominated by crude-oil production. The oil sector has positively influenced the rest of the economy of Kuwait through financial linkages, increased aggregate demand, and expanded imports. The subsequent exploitation of its oil reserves leads to the phenomenal growth of the Kuwaiti economy. Certain factors helped the domestic productive forces in shaping the characteristic features of the Kuwaiti Stock Exchange. This remarkable development owes much to the oil revenues. However, besides the oil prices, which previous studies have confirmed affect the Kuwaiti Stock Exchange, other factors that have been documented in the stock market literature during the last few decades can also have an impact on the Kuwaiti Stock Exchange. Therefore, this study investigates the dynamic long- and short-run relationship between the general index of Kuwaiti Stock Exchange and macroeconomic variables such as: the money supply (M2, henceforth), the consumer price index (CPI, henceforth), as a proxy for inflation, the US dollar/Kuwaiti dinar exchange rate (EX, henceforth) and the oil prices (crude oil, the average spot price of Brent and Dubai and West Texas Intermediate, equally weighed).

\section{The Empirical Work and the Results}

\subsection{Data}

The data used in this study were taken from the Kuwaiti Stock Exchange and Central Bank of Kuwait websites and oil prices form OECD (2019). The sample period consists of monthly data for the period 2005-2018. The variables which will be tested in this study are as follows: the all share index (KSEI, henceforth. The base date is 29 December $1993=1000)$, money supply (M2, henceforth), oil prices (OIL, henceforth), 3-month interest rate on deposit (INT, henceforth), consumption price index (CPI, henceforth) and exchange rate of US dollar vs KD (EX, henceforth).

\subsection{Methodology}

The main objective of this study is to examine the dynamic long- and short-run relationships between stock prices (KSEI), and selected macroeconomic variables. These variables are: the money supply (M2), oil prices (Oil), 3-month deposit interest rate (INT), consumer price index (CPI, as a proxy for inflation) and the exchange rate of US dollars vs the Kuwaiti dinar (EX). Cointegration methods and VECM will be applied in this study. All of the empirical work was done by using EViews 9SV. The empirical work starts by examining the non-stationarity of the variables at their level $I(0)$ by the Augmented Dickey-Fuller unit roots test. If the results of this test confirm that all of the variables are non-stationary at their level, and become stationary when the first deference has taken, we apply the Johansen (1998) cointegration test. Depending on the outcome results, if the cointegration shows that the variables are cointegrated, the Var Error Correction Model (VECM) will be used. Otherwise, the Unrestricted Vector (UVAR) will be applied in case no cointegration is obtained. The EViews program has been used for the 
empirical work.

\subsection{Descriptive Statistics}

Table 1. Descriptive Statistics

\begin{tabular}{|c|c|c|c|c|c|c|}
\hline & KSEI & M2 & Oil & CPI & EX & INT \\
\hline Mean & 8.918563 & 10.15371 & 4.267137 & 4.841309 & 5.663999 & 0.476151 \\
\hline Median & 8.838131 & 10.22841 & 4.274024 & 4.875960 & 5.665551 & 0.253091 \\
\hline Maximum & 9.645765 & 10.55631 & 4.889070 & 5.027820 & 5.722146 & 1.686769 \\
\hline Minimum & 8.462889 & 9.382595 & 3.393837 & 4.589041 & 5.580759 & -0.314711 \\
\hline Std. Dev. & 0.285070 & 0.336685 & 0.333008 & 0.114393 & 0.036105 & 0.658117 \\
\hline Skewness & 0.796600 & -0.789268 & -0.183231 & -0.334682 & -0.193433 & 0.577271 \\
\hline Kurtosis & 2.827845 & 2.449135 & 2.085735 & 1.908963 & 2.342987 & 1.972325 \\
\hline Observations & 165 & 165 & 165 & 165 & 165 & 165 \\
\hline
\end{tabular}

Source: Prepared by the authors.

Table 1 shows the descriptive statistics for all logarithm variables. The kurtosis statistic shows that all of the variables are less than three, which indicates that the distribution is leptokurtic and has a thinner tail. However, the skewness statistic indicates four variables with negative distribution (M2, Oil, CPI and EX) while KSEI and INT have a positive departure to the right from symmetry.

\subsection{Unit Root Test}

The Augmented Dickey-Fuller (ADF), the unit root test, was applied at all levels of the variables to check whether our variables are stationary or not at their level. These tests are as follows:

1. Null hypothesis: Variable has a unit root. (not stationary)

2. Alternative hypothesis: Variable does not have a unit root. (stationary)

If the p-values $<.05$, that means that the data are stationary, and the null hypothesis is rejected. Moreover, if the t-statistic $>$ critical values, the null hypothesis is also rejected. Tables 2-7 show that all of the variables at their level are nonstationary, while first deference makes all of the variables stationary.

Table 2. Augmented Dickey-Fuller unit test results for KSEI

\begin{tabular}{lcc}
\hline Variable & Level & $\Delta$ Level \\
\hline Prop* & 0.3497 & 0.0000 \\
t-Statistic** & -1.861867 & -8.212731 \\
Test critical values; & & \\
$1 \%$ & -3.470179 & -3.470179 \\
$5 \%$ & -2.878937 & -2.878937 \\
$10 \%$ & -2.576124 & -2.576124 \\
\hline
\end{tabular}

Source: Prepared by the authors.

*MacKinnon (1996) one-sided p-values, denotes stationary less than 0.05

** Significant, t-Statistics must be $>$ critical values.

Table 3. Augmented Dickey-Fuller unit test results for M2

\begin{tabular}{lcc}
\cline { 2 - 3 } Variables & Level & $\Delta$ Level \\
\cline { 2 - 3 } Prop. ${ }^{*}$ & 0.4914 & 0.0000 \\
t-Statistic** & -1.578360 & -13.49535 \\
Test critical values; & & \\
$1 \%$ & -3.469933 & -3.470179 \\
$5 \%$ & -2.878829 & -2.878937 \\
$10 \%$ & -2.576067 & -2.576124 \\
\hline
\end{tabular}

Source: Prepared by the authors.

* MacKinnon (1996) one-sided p-values, denotes stationary less than 0.05.

** Significant, t-Statistics must be $>$ critical values. 
Table 4. Augmented Dickey-Fuller unit test results for Oil prices

\begin{tabular}{lcc}
\hline Variables & Level & $\Delta$ Level \\
\hline Prop. ${ }^{*}$ & 0.0740 & 0.0000 \\
t-Statistic** & -2.712420 & -7.834410 \\
Test critical values; & & \\
$1 \%$ & -3.469933 & -3.469933 \\
$5 \%$ & -2.878829 & -2.878829 \\
$10 \%$ & -2.576067 & -2.878829 \\
\hline
\end{tabular}

Source: Prepared by the authors.

* MacKinnon (1996) one-sided p-values, denotes stationary less than 0.05 .

** Significant, t-Statistics must be $>$ critical values.

Table 5. Augmented Dickey-Fuller unit test results for CPI

\begin{tabular}{lcc}
\hline Variables & Level & $\Delta$ Level \\
\hline Prop. ${ }^{*}$ & 0.5457 & 0.0000 \\
t-Statistic** & -1.471604 & -13.28935 \\
Test critical values; & & \\
$1 \%$ & -3.469691 & -3.469933 \\
$5 \%$ & -2.878723 & -2.878829 \\
$10 \%$ & -2.576010 & -2.576067 \\
\hline
\end{tabular}

Source: Prepared by the authors.

* MacKinnon (1996) one-sided p-values, denotes stationary less than 0.05 .

** Significant, t-Statistics must be $>$ critical values.

Table 6. Augmented Dickey-Fuller unit test results for EX

\begin{tabular}{lcc}
\hline Variables & Level & $\Delta$ Level \\
\hline Prop. ${ }^{*}$ & 0.4779 & 0.0000 \\
t-Statistic** & -1.604704 & -6.707717 \\
Test critical values; & & \\
$1 \%$ & -3.470679 & -3.470679 \\
$5 \%$ & -2.879155 & -2.879155 \\
$10 \%$ & -2.576241 & -2.576241 \\
\hline
\end{tabular}

Source: Prepared by the authors.

*MacKinnon (1996) one-sided p-values, denotes stationary less than 0.05 .

** Significant, t-Statistics must be $>$ critical values.

Table 7. Augmented Dickey-Fuller unit test results for INT

\begin{tabular}{lcc}
\hline Variables & Level & $\Delta$ Level \\
\hline Prop. $^{*}$ & 0.7664 & 0.0000 \\
t-Statistic** & -0.960786 & -7.284658 \\
Test critical values; & & \\
$1 \%$ & -3.469933 & -3.469933 \\
$5 \%$ & -2.878829 & -2.87882 \\
$10 \%$ & -2.576067 & -2.576067 \\
\hline
\end{tabular}

Source: Prepared by the authors.

*MacKinnon (1996) one-sided p-values, denotes stationary less than 0.05

** Significant, t-Statistics must be $>$ critical values.

Table 2-7 show that the p-values and t-Statistics for all of the variables are non-stationary at their level and they became stationary after the first deference is taken. In the next step, the Johansen cointegration test is applied to the levels of all variables.

\subsection{Johansen Cointegration Test}

The Johansen (1998) Cointegration Test was applied in the study and all data were transformed into a natural logarithm prior to the analysis. However, before the Johansen Cointegration Test was applied, the VAR lag order selection criteria were tested for the time series. According to the Akaike information criterion (AIC), the optimal lag is 3 . The following hypothesis was tested to investigate the cointegration, assuming the intercept (no trend) in 
CE, and test the VAR for our target variable KSEI and other variables:

1. Null hypothesis: there is no cointegration in this model.

2. Alternative hypothesis: there is cointegration in this model.

Table 8. Unrestricted Cointegration Rank Test (Trace)

\begin{tabular}{lcccc}
\hline $\begin{array}{l}\text { Hypothesized } \\
\text { No. of CE(s) }\end{array}$ & Eigenvalue & Trace Statistic & $\begin{array}{c}0.05 \\
\text { Critical Value }\end{array}$ & Prob.** \\
\hline Non* & 0.239440 & 113.7492 & 95.75366 & 0.0016 \\
At most $1 *$ & 0.187697 & 69.95712 & 69.81889 & 0.0487 \\
At most 2 & 0.131982 & 36.69594 & 47.85613 & 0.3620 \\
At most 3 & 0.058390 & 14.04909 & 29.79707 & 0.8379 \\
At most 4 & 0.027175 & 4.422761 & 15.49471 & 0.8666 \\
At most 5 & $9.10 \mathrm{E}-05$ & 0.014556 & 3.841466 & 0.9038 \\
\hline
\end{tabular}

Source: Prepared by the authors.

* Trace test indicates two cointegrating equations at the 0.05 level.

$* *$ denotes rejection of the null hypothesis at the 0.05 level if Prob. $<0.05$.

***MacKinnon-Haug-Michelis (1999) p-values.

Table 9. Unrestricted Cointegration Rank Test (Maximum Eigenvalue)

\begin{tabular}{lcccc}
\hline $\begin{array}{l}\text { Hypothesized } \\
\text { No. of CE(s) }\end{array}$ & Eigenvalue & $\begin{array}{l}\text { Max-Eigen } \\
\text { Statistic }\end{array}$ & $\begin{array}{c}0.05 \\
\text { Critical Value }\end{array}$ & Prob. \\
\hline None * & 0.239440 & 43.79210 & 40.07757 & 0.0183 \\
At most $1 *$ & 0.187697 & 33.26118 & 33.87687 & 0.0591 \\
At most 2 & 0.131982 & 22.64685 & 27.58434 & 0.1891 \\
At most 3 & 0.058390 & 9.626331 & 21.13162 & 0.7789 \\
At most 4 & 0.027175 & 4.408205 & 14.26460 & 0.8139 \\
At most 5 & $9.10 \mathrm{E}-05$ & 0.014556 & 3.841466 & 0.9038 \\
\hline
\end{tabular}

Source: Prepared by the authors.

* Indicates 2 cointegrating eqn(s) at the 0.05 level.

Table 8-9 show the results of the Johansen Cointegration Test. There are two cointegration equations at the 5\% level. These results indicate that these variables move together, so the Vector Error Correction Model (VECM), using (p-1) lags, may provide the best option for testing the short- and long-run dynamic relationships between the KSEI and Oil, M2, INT, CPI, and EX. This model can be written as follows:

$$
\begin{gathered}
\mathrm{VECM} ; \Delta K S E I_{t}=\sigma+\sum_{i=1}^{n-1} \beta_{i} \Delta K S E I_{t-i}+\sum_{j=1}^{n-1} \delta_{j} \Delta O I L_{t-j}+\sum_{d=1}^{n-1} \zeta_{d} \Delta M 2 x_{t-d}+\sum_{m=1}^{n-1} \xi_{m} \Delta I N T_{t-m}+ \\
\sum_{s=1}^{n-1} \mathrm{q}_{s} \Delta C P I_{t-s}+\sum_{r=1}^{n-1} Q_{r} \Delta E X_{t-r}+\emptyset_{t-1}+\mu_{t}
\end{gathered}
$$

The OLS residual from the long-run cointegration regression is the ECT (Z). The coefficient of ETC ( $\varnothing)$ measures the speed at which y returns to equilibrium after a change in $\mathrm{x}$.

For the long-run relationship:

Cointegrating equation:

$$
z_{t-1}=E C T_{t-1}=y_{t-1}-\beta_{0}-\beta_{1} x_{t-1}
$$

Based on equation 1, the VECM for the Kuwaiti Stock Exchange Index (KSEI), as a target variable, was estimated and the following results obtained:

$$
\begin{aligned}
& \Delta l K S E I_{t}=-0.024639 l \mathrm{ISSEI}_{t}+0.67 l M 2_{t-1}+0.668 \mathrm{lINT}_{t-1}+1.623 \mathrm{lOIL} L_{t-1}+17.116 l E X_{t-1}+4.278 l C P I_{t-1} \\
& -140.652+0.193 \Delta l K S E I_{t-1}+0.085 \Delta l K S E I_{t-2}-0.0076 \Delta l M 2_{t-1}+0.354164 \Delta L M 2_{t-2}+0.006273 \\
& \Delta L_{I N T} T_{t-1}+0.099 \Delta \text { LINT }_{t-2}+0.159 \Delta \text { LOIL }_{t-1}+0.0503 \Delta L O I L_{t-2}+0.567 \Delta L E X_{t-1}{ }^{-} \\
& 0.0483 \Delta E X_{t-2}+0.083957 \Delta L C P I_{t-1}+0.0785 \Delta L C P I_{t-2}-0.005608
\end{aligned}
$$

For long-run associated:

$$
\begin{array}{ccccc}
E C T_{t-1}=l K S E I_{t-1}+0.67 l M 2_{t-1}+0.668 & l I N T_{t-1}+1.623 & l O I L_{t-1}+17.116 & l E X_{t-1}+4.278 & l C P I_{t-1}-140.652 \\
(2.2285) & (3.753)
\end{array}
$$


Table 10 shows that the speed of adjustment to the long-run equilibrium (the coefficient of $E_{C T} T_{t-1}(\mathrm{C} 1)$ ) has a p-value less than 0.05 and a negative sign, which satisfies both conditions. This coefficient supports a long-term association so, if the Kuwaiti Stock Market Index rises, other variables will be pulled back by $2.4 \%$ to reach equilibrium in the long-run. There is evidence that there exists long-run causality between the KSEI and all selected macroeconomic variables, and that this relationship is positive. The relationship between the money supply (M2) and stock prices is positive. This result is in line with other studies which found a positive relationship between these two variables. However, a high growth in the money supply will cause an increase in the cash flow of the listed companies, which will lead to an increase in stock prices through their dividends (Patel, 2012). These results were compared with those of other studies, for example: Sellin (2001); Maskay (2007); Gowriah, Seetanah, John and Keshav (2014); Ndunda, Kingori and Ariemba (2016); and Abbas et al. (2017). These studies find a positive relationship between the stock exchange and money supply. Maskay (2007) argues that this positive relationship might be explained by the real activity of economists, who believe that shocks by a positive money supply provide an indicator for investors that the economic activity is increasing. This suggests increasing the cash flows, which leads to higher stock prices (Maskay, 2007, p. 73). Growriah et al. (2014) argue that money supply growth will affect the real interest rates negatively, which will push the Central Bank to cut the discount rate. As a result, the stock prices will increase, through the present value mechanism (Gowriah et al. 2014). As a result, increasing the money supply will increase the stock prices in the long-run to reach an equilibrium position. However, Keynesian economists believe in a different way, arguing that increasing the money supply may give the stockholders an indicator about the squeeze monetary policy in the future. As a result, the interest will increase and negatively affect the stock prices (Maskay, 2007).

The positive association shown in our results between the three-month interest rate (INT) and the Kuwaiti Stock Price Index was unexpected. Al-Shami and Ibrahim (2013) also find a positive relationship between stock return on the KSE two months later while they revealed a negative relationship one month later. Merza and Amusawi (2016) found the same result and argue that this is confusing behaviour. Although this phenomenon of a positive relationship between KSEI and the interest rate conflict with the theory and logic, KSE has witnessed during some periods of its life (1977 and 1982) a high interest rate with a high increase in stock prices, which can be explained by speculators' behaviour. As mentioned earlier in this study, government consumption plays a crucial role in the economy. However, the interest rate on a three-month deposit is an alternative investor opportunity, so we assume that rational investors will prefer less risky investment tools. Many studies find the opposite results, which can be more logical according to the economic theory, such as Olugbenga (2011) who finds a negative impact of interest rate for Nigerian Stock prices, and Barakat, Elgazzar and Hanafy (2016) for the Egyptian and Tunisian Stock Markets.

As mentioned earlier, oil plays a crucial role in the Kuwaiti economy and is the main source of liquidity within it. Oil prices are expected to affect the stock prices positively in exporting countries while negatively affecting the stock prices in importing countries. This is because high oil prices cause high inflation in importer countries. The findings of this study show that oil prices have a positive relationship with stock prices on the Kuwaiti Stock Exchange. This result reflects the impact of oil on the Kuwaiti economy and stock exchange, and is supported by others who found a positive relationship, such as: Olugbenga (2011), Samontarary, Nugali and Sasidhar (2014); Al Hayky and Naim (2016); and Kalyanaraman and Al-Tuwajiri (2014).

The Kuwaiti Stock Index and the exchange rate have a positive long-run relationship. The Kuwaiti dinar (KD) is pegged to a basket of currencies. However, the depreciation of the KD against the US dollar will affect the government's budget since the oil prices are in US dollars, and at the same time will increase the foreign inflow into the KSE. This result is in line with a study of the Istanbul Stock Market by Karagoz, Ergun and Karagoz (2009), while Ndunda, Kingori and Ariemba (2016) find a positive relationship between the two variables for the Nairobi Stock Market. However, a negative relationship between exchange rate and stock market were found in other studies, such as Olugbenga (2011) for the Nigerian Stock Market and Kuwornu (2011) for the Ghanian Stock Market.

This study finds that the inflation rate (CPI) has positive effects on the KSE. There are two debates in the literature regarding the relationship between inflation and stock prices; for example, Fisher (1930) argues that this relationship is positive, while Fama (1981) argues that a high inflation rate will affect the real activity of the economy and stock market returns negatively. Our result is consistent with other studies that find a positive relationship between inflation and stock prices, for example: Choudhry (2001), Karagoz, Ergun and Karagoz (2009), Al-Shami and Ibrahim (2013), Olufisayo (2013), Ahmed, Islam and Khan (2015) and Ndunda, Kingori and Ariemba (2016). However, opposing results were found in other studies, which find a negative relationship between these two variables, such as Fama (1981, 1990), Spyrou (2001), Sohail and Hussain (2009) and Saleem, 
Zafar, and Rafique (2013). It is worth mentioning that all of the relationships are unidirectional, from the macroeconomic variables to the KSE.

Table 10. Coefficients from the results of the least squares (Gauss-Newton/Marquardt steps)

\begin{tabular}{ccccc}
\hline Variable & Coefficient & Std. Error & t-Statistic & Prob. \\
\hline $\mathrm{C}(1) l K S E I_{t-1}$ & -0.024639 & 0.011430 & -2.155576 & 0.0327 \\
$\mathrm{C}(2) \Delta l K S E I_{t-1}$ & 0.193733 & 0.080453 & 2.408033 & 0.0173 \\
$\mathrm{C}(3) \Delta l K S E I_{t-2}$ & 0.085049 & 0.082423 & 1.031857 & 0.3038 \\
$\mathrm{C}(4) \Delta l M 2_{t-1}$ & -0.007605 & 0.222761 & -0.034138 & 0.9728 \\
$\mathrm{C}(5) \Delta l M 2_{t-2}$ & 0.354164 & 0.222165 & 1.594150 & 0.1130 \\
$\mathrm{C}(6) \Delta L I N T_{t-1}$ & 0.006273 & 0.088008 & 0.071278 & 0.9433 \\
$\mathrm{C}(7) \Delta L I N T_{t-2}$ & 0.099656 & 0.086051 & 1.158103 & 0.2487 \\
$\mathrm{C}(8) \Delta L O I L_{t-1}$ & 0.159303 & 0.053690 & 2.967086 & 0.0035 \\
$\mathrm{C}(9) \Delta L O I L_{t-2}$ & 0.050375 & 0.057421 & 0.877283 & 0.3817 \\
$\mathrm{C}(10) \Delta L E X_{t-1}$ & 0.567191 & 0.940142 & 0.603304 & 0.5472 \\
$\mathrm{C}(11) \Delta L E X_{t-2}$ & -0.048394 & 0.888763 & -0.054451 & 0.9566 \\
$\mathrm{C}(12) \Delta l C P I_{t-1}$ & 0.083957 & 0.151647 & 0.553634 & 0.5807 \\
$\mathrm{C}(13) \Delta l C P I_{t-2}$ & 0.078569 & 0.149655 & 0.524998 & 0.6004 \\
$\mathrm{C}(14)$ Intercept & -0.005608 & 0.004626 & -1.212231 & 0.2273 \\
\hline
\end{tabular}

Source: prepared by the authors.

* Negative and Prob. below the below 0.05 level.

Table 11-15 report the results of the Wald test for the couple coefficients for each variable, in order to investigate whether or not the variables have a short-run relationship with the KSEI. Tables 11-15 show that the null hypothesis for each couple of coefficients $[C(4)=C(5)=0, C(6)=C(7)=0, C(10)=C(11)=0$, and $C(12)=C(13)=0]$ cannot be rejected, except for oil coefficients $[C(8)=C(9)=0]$, which reject the null hypotheses. As a result, only oil prices have a short-run relationship with KSEI, which reflects the importance of oil prices for Kuwait stock prices, which have long- and short-run positive relationship with stock prices. This is in line with studies such as: Maghyereh and Al-Kandari (2007), Ravichandran and Alkhathlan (2010), Mohanty, Nandhs, Turkistani and Alaitani (2011), and Chiekh, Naceur, Kanaan and Rault (2018). However, other variables do not influence the stock prices in the short-run. In other words, there is no short-run causality from all selected macroeconomic variables, except for oil prices, to stock prices in the KSE.

Table 11. Test the Null Hypothesis that (M2) does not cause stock prices in the short-run

\begin{tabular}{lccc}
\hline Test Statistics & Value & df & Probability* \\
\hline F-statistic & 1.296978 & $(2,149)$ & 0.2764 \\
Chi-square & 2.593957 & 2 & 0.2734 \\
\hline
\end{tabular}

Source: Prepared by the authors.

*p-value $>0.05$ level.

Table 12. Test the Null Hypothesis that INT do not cause stock prices in the short-run

\begin{tabular}{lccc}
\hline Test Statistics & Value & df & Probability* \\
\hline F-statistic & 0.922452 & $(2,149)$ & 0.3998 \\
Chi-square & 1.844903 & 2 & 0.3975 \\
\hline
\end{tabular}

Source: Prepared by the authors.

*p-value $>0.05$ level.

Table 13. Test the Null Hypothesis that Oil prices do not cause stock prices in the short-run

\begin{tabular}{lccc}
\hline Test Statistics & Value & df & Probability* \\
\hline F-statistic & 5.560452 & $(2,149)$ & 0.0047 \\
Chi-square & 11.12090 & 2 & 0.0038 \\
\hline
\end{tabular}

Source: Prepared by the authors.

*p-value $<0.05$ level. 
Table 14. Test the Null Hypothesis that Exchange Rate do not cause stock prices in the short-run

\begin{tabular}{lccc}
\hline Test Statistics & Value & df & Probability* \\
\hline F-statistic & 0.221114 & $(2,149)$ & 0.8019 \\
Chi-square & 0.442227 & 2 & 0.8016 \\
\hline
\end{tabular}

Source: Prepared by the authors.

$*$ p-value $<5 \%$ level.

Table 15. Test the Null Hypothesis that CPI do not cause stock prices in the short-run

\begin{tabular}{lccc}
\hline Test Statistics & Value & $\mathrm{df}$ & Probability* \\
\hline F-statistic & 0.260164 & $(2,149)$ & 0.7713 \\
Chi-square & 0.520328 & 2 & 0.7709 \\
\hline
\end{tabular}

Source: Prepared by the authors.

$*$ p-value $<5 \%$ level.

\subsection{Serial Correlation}

We proceed next with the Breusch-Godfrey serial correlation LM test for the serial correlation. The hypothesis can be written as follows:

1. Null hypothesis: there is no serial correlation between the variables.

2. Alternative hypothesis: there is a serial correlation between the variables.

Table 16. Breusch-Godfrey Serial Correlation LM Test

\begin{tabular}{llll}
\hline F-statistic & 1.307148 & Prob. F(2,147) & 0.2737 \\
\hline Obs*R-squared & 2.848191 & Prob. Chi-Square(2) & 0.2407 \\
\hline
\end{tabular}

Source: Prepared by the authors.

*Significant $>0.05$.

Table 16 shows that, due to the significant results for the p-value, which is $>0.05$, we cannot reject the null hypothesis. There is no evidence of a serial correlation in this model. As a next step, we test the heteroskedasticity in our model.

\subsection{Heteroskedasticity Test}

1. Null hypothesis: there is no heteroskedasticity in the model.

2. Alternative hypothesis: there is a heteroskedasticity in the model.

Table 17. Heteroskedasticity Test: Breusch-Pagan-Godfrey

\begin{tabular}{llll}
\hline F-Statistic & 0.776081 & Prob. F(18,144) & 0.7252 \\
\hline Obs*R-squared & 14.41432 & Prob. Chi-Square(18) & 0.7017 \\
\hline
\end{tabular}

Source: Prepared by the authors.

*significant $>0.05$.

Table 17 clearly shows that there is no heteroskedasticity in the model and that all of the statistical tests, such as the p-value and prob. Chi-Square, are significant at level 1 and $>0.05$, so the null hypothesis cannot be rejected. However, to ensure the dynamic stability of the model, the stability diagnostics were tested by the Cumulative sum (CUSUM) chart. Figure 4 shows that the CUSUM line (blue) lies within the 5\% significance level, which provides evidence that the model is dynamically stable in the long-run. 


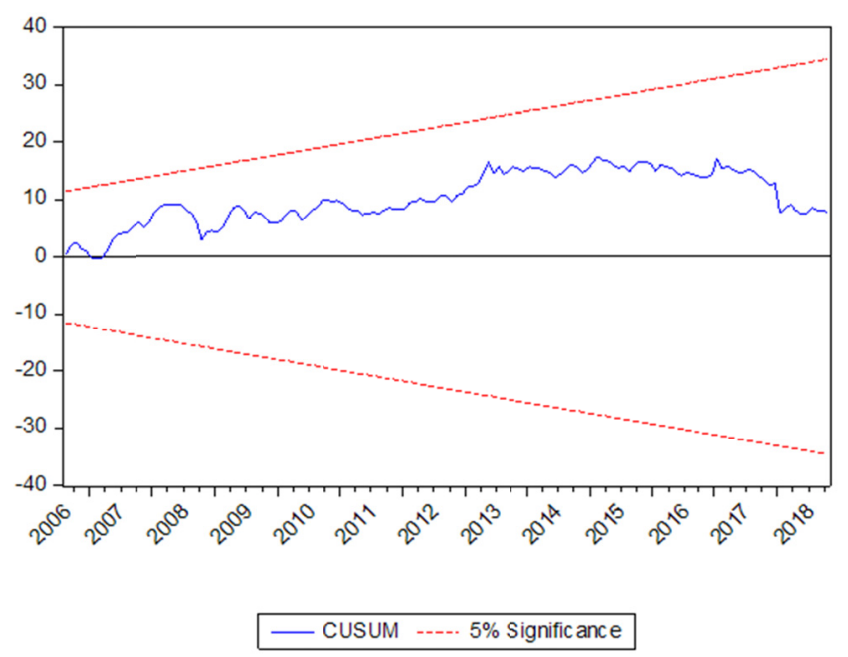

Figure 3. Cusum chart

\section{Conclusion}

This study examined the long- and short-run relationships between stock prices and selected macroeconomic variables in Kuwait. These variables are: oil prices, the money supply (M2), the three-month deposit interest rate, inflation (consumer price index) and the exchange rate of the US dollar vs the Kuwaiti Dinar. The time series included monthly data for the period January 2005- December 2018. To our knowledge, few studies have examined the relationship between stock prices and macroeconomic variables, and these include: Al-Mutairi and Al-Omar (2007); Al-Shami and Ibrahim (2013); Al-Hayky and Naim (2016); and Merza and Almusawi (2016). This study concluded that there is a unidirectional, positive long-run relationship between the selected macroeconomic variables and the Kuwaiti Stock Exchange Index (KSEI). This study confirmed a short-run relationship between oil prices and stock prices in Kuwait, which reflects the role of oil in the Kuwait Stock Exchange, which is an important sector of the economy. Moreover, no short-run relationship was found for the other selected macroeconomic variables. The findings of this study are in line with those of other studies, such as: Sellin (2001); Maskay (2007); Al-Shami and Ibrahim (2013); Gowriah, Seetanah, John and Keshav (2014); and Abbas et al. (2017). However, the limitations of this research that it does not include the GDP and the industrial production index. It would be helpful to conduct further research that included the GDP data which currently unavailable on monthly basis. Moreover, the Kuwait Stock Market recently witnessed remarkable regulatory development, therefore, it calls for more studies such as the need to test for the volatility of the KSE, studying the day-of-the week effect, and the month-of the year effect on the KSE.

\section{References}

Abbas, G., Bhowmik, R., Koju, L., \& Wang, S. (2017). Cointegration and Causality Relationship Between Stock Market, Money Market and Foreign Exchange Market in Pakistan. Journal of Systems Science and Information, 5(1), 1-20. https://doi.org/10.21078/JSSI-2017-001-20

Ahmed, S. F., Islam, K. M. Z., \& Khan, R. (2015). Relationship between Inflation and stock market returns: Evidence from Bangladesh. Daffodil International University Journal of Business and Economics, 9(1), 1-12.

Ahmed, W., Aslam, A., \& Hakeem, A. (2018). The Influence of Macro-Economic Factors on Stock Prices of KSE 100 Index. International Journal of Research and Scientific Invention, 5(11), 35-44. Retrieved from https://www.researchgate.net/publication/329336938_The_Influence_of_Macro-Economic

Ajayai, R. A., \& Mougoue, M. (1996). On the dynamic relation between stock price and Exchange rates. The Journal of Financial Research, 19, 193-207.

Alam, M., \& Uddin, G. S. (2009). Relationship between Interest Rate and Stock Price: Empirical Evidence from Developed and Developing Countries. International Journal for Business and Management, 4(3), 43-51. https://doi.org/10.5539/ijbm.v4n3p43

Al-Hayky, A., \& Naim, N. (2016). The Relationship between Oil price and Stock Market Index: An Empirical Study from Kuwait. INTERNAL SEMINARS dated 29/3/2016. College of Business and Finance, Ahlia 
University in Bahrain.

Al-Mutairi, A., \& Al-Omar, H. (2007). Macroeconomic Determinants of the Behavior of the Kuwait Stock Exchange. Studies in Business and Economic, 13(1), 39-50.

Alqattan, A. A., \& Alhayky, A. (2016). Impact of Oil Prices on Stock Markets: Evidence from Gulf Cooperation Council (GCC) financial Markets. Amity Journal of Finance, 1(1), 1-8.

Al-Shami, H., \& Ibrahim, Y. (2013). The Effects of Macro-economic Indicators on Stock Returns Evidence from Kuwait Stock Exchange. American Journal of Economics, 3(5), 57-66. https://doi.org/10.5923/c.economics.20130.11

Badullahewage, S. (2018). The Effects of Macroeconomic Factors on the performance of the Stock Market in Sri Lanka. International Journal of Innovation and Economic Development, 3(6), 33-41. https://doi.org/10.18775/ijied.1849-7551-7020.2015.36.2002

Barakat, R. M., Elgazzar, S. H., \& Hanafy, K.M. (2016). Impact of Macroeconomic Variables on Stock Markets: Evidence from Emerging Markets. International Journal of Economics and Finance, 8(1), 195-207.

Bernanke, B. S., \& Kuttner, K. N. (2005). What Explains the Stock Market's Reaction to Federal Reserve Policy? The Journal of Finance, 60(7), 1221-1257. https://doi.org/10.1111/j.1540-6261.2005.00760.x

Bhatti, U. (2018). Impact of Macroeconomic Factors on Stock Market: The Study on London Stock Exchange.

Cheikh, N. B., Naceur, S. B., Kanaan, O., \& Rault, C. (2018) Oil Prices and GCC Stock Markets: New Evidence from Smooth Transition Models. IMF Working Paper, WP/18/98, International Monetary Fund, Washington DC.

Choudhry, T. (2001) Inflation and rates of return on stocks: evidence from high inflation countries. Journal of International Financial Markets, Institutions and Money, 11(1), 75-96.

Dickey, D. A., \& Fuller, W. A. (1979). Distribution of the estimations for autoregressive time series with a unit root. Journal of the American Statistical Association, 47, 427-31.

Engle, R. F., \& Granger, C. W. J. (1987). Co-integration and error correction: representation, estimation and testing. Econometrica, 55(5), 286-301.

Fama, E. (1981). Stock Returns, Real Activity, Inflation and Money. American Economic Review, 71, 545-565.

Fama, E. (1990). Term-Structure Forecasts of Interest Rates, Inflation, and Real Returns. Journal of Monetary Economics, 25, 59-76.

Fisher, I. (1930). The Theory of Interest. New York: Macmillan

Gowriah, S., Seetanah, B., John, L.M., \& Keshav, S. (2014). The effects of monetary and fiscal policies on the stock exchange: evidence from an Island economy. The Business and Management Review, 4(4), 321-332.

Ismail, M. T., Che Rose, F. Z., \& Rosmanjawati, A. R. (2017). The dynamic relationship between selected Asian stock markets and their Macroeconomic variables. Journal of Fundamental and Applied Sciences, 9(5S), 868-897. http://dx.doi.org/10.4314/jfas.v9i5s.62

Kalyanarman, L., \& Al-Tuwajri, B. (2014). Macroeconomic Forces and Stock Prices: some empirical Evidence from Saudi Arabia, International Journal of Financial Research, 5(1), 81-92.

Karagoz, K., Ergun, S., \& Karagoz, M. (2009). Impact of Macro Factors on Stock Market: Evidence from Istanbul Stock Exchange. International Symposium on Sustainable Development .

Kisswani, K., \& Elian, M. (2017). Exploring the nexus between oil prices and sectoral stock prices: Nonlinear evidence from Kuwait stock exchange. Cogent Economics and Finance, 5, 1-17.

Kuwornu, J. K. M. (2011). Macroeconomic Variables and Stock Market Returns: Full Information Maximum Likelihood Estimation. Research Journal of Finance and Accounting, 2(4), 49-63.

Maghyereh, A., \& Al-Kandari, A. (2007). Oil prices and stock markets in GCC countries: new evidence from nonlinear cointegration analysis. Managerial Finance, 33(7), 449-460. https://doi.org/10.1108/03074350710753735

Maskay, B. (2007). Analyzing the Effect of Change in Money Supply on Stock Prices. The Park Place Economist, 15 .

Masuduzzaman, M. (2012). Impact of the Macroeconomic Variables on the stock market returns: the case of Germany and the United Kingdom. Global Journal of Management and Business Research, 12(16), 14-26. 
Merza, E., \& Almusawi, S. (2016) Factors Affecting the Performance of Kuwait stock exchange. Journal of Sustainable Development, 9(5), 23-32 https://doi.org/10.5539/jsd.v9n5p23

Mohanty, S. K., Nandhs, M., Turkistani, A. Q., \& Alaitani, M. Y. (2011). Oil price movements and stock market return: Evidence from Gulf Cooperation Council (GCC) countries. Global Finance Journal, 22(1), 42-55.

Momani, G., \& Alsharari, M. (2012). Impact of Economic Factors on the Stock Prices at Amman Stock Market (1992-2010). International Journal of Economics and Finance, 4(1), 151-159. https://doi.org/10.5539/ijef.v4n1p151

Ndunda, A., Kingori, R., \& Areimba, J. (2016). Effect of Macro Economic Factors on the Performance of the Equity Market of Nairobi Securities Exchange. International Journal of Business and Commerce, 5(9), 22-33.

Nijam, I., \& Musthafa. (2015). The impact of Macroeconomic Variables on stock market performance; evidence from Sri Lank. Journal of Emerging Trends in Economics and Management Sciences, 6(2), 151-157.

OECD. (2019). Crude oil import prices (indicator). https://doi.org/10.1787/9ee0e3ab-en

Olufisayo, A. O. (2013). Stock Prices and Inflation: Evidence from Nigeria. American Journal of Economics, 3(6), 260-267. https://doi.org/10.5923/j.economics.20130306.03

Olugbenga, A. A. (2011). The Impact of Macroeconomic Indicators on Stock Prices in Nigeria. Developing Country Studies, 1(2), 1-14.

Patel, S. (2012). The effect of Macroeconomic Determinants on the Performance of the Indian Stock Market. NMIMS Management Review, 22, 117-127.

Prazak, T. (2018). The Effect of Economic Factors on Performance of the Stock Market in the Czech Republic. ACTA Universitatis Agriculture ET Silviculture Brunensis, 66(162), 1613-1626. https://doi.org/10.11118/actaun201866061613

Ravichandran, K., \& Alkhathlan, K. (2010). Impact of Oil Prices on GCC Stock Market. Research Applied Economics, 2(1), 1-12. https://doi.org/10.5296/rae.v2i1.435

Saleem, F., Zafar, L., \& Rafique, B. (2013). Long-run Relationship between Inflation and Stock Return: Evidence from Pakistan. Academic Research International, 4(2), 407-415. https://doi.org/10.12691/ijefm-5-2-4

Samontaray, D. P., Nugali, S., \& Sasidhar, B. (2014). A Study of the Effect of Macroeconomic Variables on Stock Market: Saudi Perspective, International Journal of Financial Research, 5(4), 121-127. https://doi.org/10.5430/ijfr.v5n4p120

Sellin, P. (2001). Monetary Policy and the Stock Market: Theory and Empirical Evidence. Journal of Economics Surveys, 14(4), 491-541. https://doi.org/10.1111/1467-6419.00147

Soenen, L. A., \& Hennigar, E. S. (1988). An Analysis of Exchange Rates, and Stock Prices; The U.S. Experience between 1980 and 1986. Akron Business and Economic Review, 19, 7-16.

Sohail, N., \& Hussain, Z. (2009) Long-run and short-run relationship between macroeconomics variables and stock prices in Pakistan: the case of Lahore Stock Exchange. Pakistan Economic and Social Review, 183-198.

Spyrou, S. I. (2001). Stock Returns and Inflation: Evidence from an Emerging Market. Applied Economics Letter, 8, 447-450. https://doi.org/10.1080/13504850010003280

Tripathi, V., \& Kumar, A. (2014). Relationship between inflation and stock returns evidence from BRICS markets using Panel Cointegration Test. International Journal of Accounting and Financial Reporting, 4(2), 647-658. https://doi.org/10.5296/ ijafr.v4i2.6671

Venkatraja, B. (2014). Impact of Macroeconomic Variable on Stock Market performance in India: An Empirical Analysis. International Journal of Business Quantitative Economics and Applied Management Research, 1(6), 71-85.

\section{Copyrights}

Copyright for this article is retained by the author(s), with first publication rights granted to the journal.

This is an open-access article distributed under the terms and conditions of the Creative Commons Attribution license (http://creativecommons.org/licenses/by/4.0/). 